Human Rights Law Review (C) The Author [2007]. Published by Oxford University Press. All rights reserved. For Permissions, please email: journals.permissions@oxfordjournals.org doi:10.1093/hrlr/ngm030

\title{
Nomadic Territories: A Human Rights Approach to Nomadic Peoples' Land Rights
}

\author{
Jérémie Gilbert*
}

\begin{abstract}
In most societies nomadic peoples face discrimination. At the heart of this discrimination frequently lies the crucial issue of property in land. The sharing of lands between nomads and settled agriculturalist societies has often led to violent confrontation. Access to land is a determining factor for many nomadic peoples as whether or not nomads have access to land will determine the survival of their mobile lifestyle. Historically nomadic peoples have not been regarded as having any rights to land because their nomadic lifestyle was not considered to fulfil the criterion of 'effective occupation' of the land. By exploring the evolution of international law regarding nomadic peoples' land rights, this article analyses how human rights law could provide nomadic peoples with rights to use their lands. Ultimately, this article argues that under the banner of international human rights law, nomadic peoples are gaining the right to live on their land in their traditional ways through the gradual establishment of a specific corpus of law dedicated to the rights of nomads.
\end{abstract}

\section{Introduction}

I cannot admit that wandering tribes have a right to keep other and superior races out of large tracts merely because they have acquired the habit of straggling over far more land than they can utilize.

Sir Charles Eliot, Kenya Land Report, $1933^{1}$

*Lecturer, Transitional Justice Institute, University of Ulster (j.gilbert@ulster.ac.uk). The author wishes to thank Prof. Koen de Feyter, Dr David Keane, Prof. Christine Bell and Catherine O'Rourke for comments on an earlier draft of this work. 
The wandering life is a life of freedom. There are no chains binding us to the same place. New landscapes and new perspectives also liberate the mind and thoughts.

\section{Nils-Aslak Valkeapaa, Sami, Norway ${ }^{2}$}

Since the dawn of mankind there has been a violent confrontation between two lifestyles: the settled and the nomadic way of life. ${ }^{3}$ The battle between Cain, the farmer, and Abel, the herder, is often viewed as an illustration of this violent clash. ${ }^{4}$ The dichotomy between settled and nomadic populations is often at the root of violent conflicts, and time and again at the heart of such confrontation is the issue of the sharing of lands between nomadic and sedentary peoples. The report of the International Commission of Inquiry on Darfur highlighted that the root cause of the conflict in the Darfur region is the competition between various tribes, particularly between sedentary tribes and nomadic tribes over natural resources as a result of desertification. ${ }^{5}$ Similarly, examining the genocide that took place in Rwanda, one of the sources of the genocide can be traced back to the distinction established during the colonial period between nomadic Tutsis and agriculturalist Hutus. ${ }^{6}$ These examples are not isolated and there has been a plethora of violent conflicts over land usage between nomadic and non-nomadic societies throughout history. ${ }^{7}$ During colonisation nomadic peoples were regarded by the colonial powers as even more 'backward' than other so-called 'savages. ${ }^{8}$ Nomadism is still seen as a thing of the past which should be abolished; consequently, the main legal approach to nomadism is

As quoted in Swift and Perry, Nomadic People Speak: Vanishing Footprints (Oxford: New Internationalist Publication, 2001) at 123.

3 See Khazanov, Nomads and the Outside World (Cambridge: Cambridge University Press, 1983). A nomadic way of life or nomadic lifestyle refers to a life organised around cyclical or seasonal patterns.

4 The battle between Cain, the farmer (the 'tiller of the ground'), and Abel, the nomad (the 'keeper of sheep'), saw the defeat of the nomad. See van den Brink et al., 'The Economics of Cain and Abel: Agro-Pastoral Property Rights in the Sahel', (1995) 31 Journal of Development Studies 373.

5 Report of the International Commission of Inquiry on Darfur to the United Nations Secretary-General, Pursuant to Security Council Resolution 1564 of 18 September 2005, 25 January 2005 at para. 203 (see also paras 52-58). See also Markakis, Pastoralism on the Margins (London: Minority Rights Group, 2004).

6 For an informed discussion, see Hintjens, 'When Identity Becomes a Knife: Reflecting on the Genocide in Rwanda', (2001) 1 Ethnicities 25. See also Lewis and Knight, The Twa of Rwanda (Copenhagen: International Work Group for Indigenous Affairs, 1995).

7 See Khazanov, supra n. 3; and Beals, Nomads and Empire Builders (New York: Citadel Press, 1965).

8 See, for example, Vignon, Un programme de politique coloniale, les questions indigènes (Paris: Plon, 1919). 
based on the idea of integration within the majority settled society. This process of forced 'sedentarisation' is often imposed upon nomads by force. ${ }^{9}$

Legally, nomadic peoples were often labelled as 'criminal' and seen as a danger to society. For example, under British colonial rule in India, nomadic tribes were 'notified' as born criminals under an 1871 law based on their nomadic lifestyle. ${ }^{10}$ Words such as 'vagabond, 'tramp' or 'wanderer' are usually attached to the notion of nomadism. For example, the Parliamentary Assembly of the Council of Europe adopted a declaration to make clear that the use of the term 'vagrants' in Article 5(1)(e) of the European Convention on Human Rights (ECHR) does not necessarily apply to people with a nomadic lifestyle. ${ }^{11}$ This resentment against nomadic peoples is reflected in international law, and nomadic peoples are often those left behind by its development. Whereas there is a large body of literature available from anthropological and sociological perspectives on specific use of nomadic lands, ${ }^{12}$ the legal literature remains quite limited. ${ }^{13}$ This article aims to address this gap. While it examines the legal theory regarding nomadic peoples' land rights, it will maintain the necessary multidisciplinary approach dictated by the subject by relying on anthropological, sociological and political sources. Based on such an approach, this article aims to evaluate the role of human rights law in ensuring nomadic peoples' access to and use of their traditional transhumant territories.

The Oxford English Dictionary traces the origins of the word 'nomad' back to the Greek nemein meaning 'to pasture', and defines a nomad as 'a member of a people continually moving to find fresh pasture for its animals and having no permanent home'. One central aspect of this definition is the link between a people on the move and the reason behind such movement, which is to find fresh pasture. Anthropological research suggests that there are three main

9 For examples and references see Noyes, 'Nomadic Landscapes and the Colonial Frontier: The Problem of Nomadism in German South West Africa', in Russell (ed.), Colonial Frontiers, Indigenous-European Encounters in Settler Societies (Manchester: Manchester University Press, 2001) at 198.

10 Criminal Tribes Act 1871, this was replaced with the Habitual Offenders Act 1959. See National Human Rights Commission of India, 'Habitual Offenders Act to be Repealed: NHRC Takes Up the Cause of the Denotified and Nomadic Tribes', March 2000.

11 Paragraph xii, Council of Europe Parliamentary Assembly Recommendation 1203 (1993) on Gypsies in Europe, 2 February 1993, at para. xii. Article 5(1)(e), ECHR makes an exception to the right to liberty and security of person for the lawful detention of persons for the prevention of the spreading of infectious diseases, of persons of unsound mind, alcoholics or drug addicts, or vagrants'.

12 See, for example, Ingold, Riches and Woodburn, Hunters and Gatherers, Volumes 1 and 2 (New York: Berg, 1991); and Lee and Daly, The Cambridge Encyclopaedia of Hunters and Gatherers (Cambridge: Cambridge University Press, 2005).

13 The existing literature usually addresses specific geographical areas of the globe but do not address the rights of nomadic peoples in a universal way. See, for example, Barume, Etude sur le cadre légal pour la protection des droits des peuples indigènes et tribaux au Cameroun (Geneva: Organisation Internationale du Travail, 2005); and Osherenko, 'Indigenous Rights in Russia: Is Title to Land Essential for Cultural Survival?', (2001) 13 Georgetown International Environmental Law Review 695. 
categories of nomadic peoples: pastoral nomads, nomadic hunter-gatherers and peripatetic service nomads. ${ }^{14}$ These categories encompass various nomadic groups from fully nomadic hunter-gatherer communities to seminomadic $^{15}$ communities such as Roma/Gypsies or Irish Travellers, who, even though not hunter-gatherers, are culturally regarded as nomadic peoples. ${ }^{16}$ The thread that links these different forms of nomadism is the idea of movement from one place to another without the existence of a fixed or permanent territory. For many nomadic peoples the possibility of travelling through their traditional territories is central to their survival; the right to access such territory is therefore crucial. At the heart of the issue of territorial entitlement is the fundamental question of whether nomadic peoples have the right to remain nomads or whether they should settle down.

This article examines the territorial entitlements of nomadic peoples under international law through three different lenses. The first part of the article goes back to the roots of the rules of international law regarding title to territory and examines their impact on nomadic peoples' land rights. Based on this assessment the article then analyses the extent to which international law remains embedded within a sedentarist approach to territory which rejects nomadic territorial entitlements, and whether the international human rights framework will ultimately make a positive difference for nomadic peoples. In order to address this issue, the second part of the article examines recent developments in human rights law regarding the rights of indigenous peoples as there is a movement towards linking nomadic peoples' land claims to the rights of indigenous peoples. ${ }^{17}$ The article critically examines the extent to which such development is relevant to nomadic peoples' land rights, with a particular focus on the development of a discourse on collective land rights. Finally, the third part of this article analyses whether human rights law offers, or should offer, specific rights to nomadic peoples to use and access their traditional territories. This part of the article scrutinises the potential development of a body of law targeted at securing rights that are particular to nomadic peoples' use of their traditional spatial territories and offers a comprehensive outline of the main characteristics of such a legal regime.

14 See Bogue, 'Apology for Nomadology', (2004) 6 Interventions 169; and Berland and Salo, 'Peripatetic Communities: An Introduction', (1986) 21/22 Nomadic Peoples 1.

15 Semi-nomadic peoples are peoples who move seasonally but have permanent homes for part of the year. See, for example, Council of Europe Committee of Ministers Recommendation (2004) 14, 1 December 2004, which refers to semi-nomadic peoples as peoples who set up their winter residence for a maximum period of six months and then move on.

16 See Liegeois and Gheorghe, Roma/Gypsies: A European Minority (London: Minority Rights Group, 1995).

17 See Schweitzer et al. (eds), Hunters and Gatherers in the ModernWorld: Conflict, Resistance, and Self-Determination (New York: Berghahn Books, 2000). 


\section{Strangers in their Own Lands: Nomadic Peoples as 'Ineffective' Occupiers of their Territories}

An obvious difficulty for nomadic peoples when asserting territorial rights is that they wander from place to place and occupy areas for a limited period of time. Thus, nomadic peoples are not regarded as legal occupiers of any particular land as they do not to have 'a fixed abode, and definite territory belonging to the people by whom it is occupied. ${ }^{18}$ The rules governing territorial ownership emerged from a Western theory that land has to be 'properly' used and occupied to provide title of ownership. However, historically, nomadic communities have not been regarded as sufficiently 'civilised' to possess rights over their territories as the nomadic system of land use was seen as an outdated and non-rational organisation of land utilisation.

\section{A. Cain and Abel's Ghosts: Nomadism versus the 'Agricultural Argument'}

From its origins the rules governing land use and ownership have been framed around the principle of 'effective occupation' of the land. From Locke to Hegel, several major authors have argued for what can be described as the cultivation test' or 'agricultural argument'. ${ }^{19}$ The 'agricultural argument' promotes the view that only cultivation of land can be regarded as a 'proper' occupation of land, and only agriculture can be regarded as a basis of a real land tenure system. In his Essay Concerning the True Original, Extent and End of Civil Government, Locke introduced the view that uncultivated land was not possessed closely enough to constitute property. ${ }^{20}$ For example, while 'Indians' had some usufructuary rights over their hunting products, they were 'commonly without any fixed property in the ground. ${ }^{21}$ For this reason, territories used by hunters and gatherers or nonsedentary agriculturists were to be regarded as vacant. The Lockean argument that rights in land arose only from appropriation and improvement of the land by agriculture was widely accepted. ${ }^{22}$ Rousseau explained the origin of private property by using the model of the development of agriculture. ${ }^{23}$

18 Wheaton, Elements of International Law (Oxford: Clarendon Press, 1936) at 18.

19 Flanagan, 'The Agricultural Argument and Original Appropriation: Indian Lands and Political Philosophy', (1989) 22 Canadian Journal of Political Science 589. See also Bassett, 'The Myth of the Nomad in Property Law', (1986) 4 Journal of Law and Religion 133.

20 See Locke, Two Treatises of Government (London: Dent, 1924).

21 Tully, Strange Multiplicity: Constitutionalism in an Age of Diversity (Cambridge: Cambridge University Press, 1995) at 72.

22 See Meek, Social Science and the Ignoble Savage (Cambridge: Cambridge University Press, 1970).

23 Rousseau, Discours sur l'origine de l'inégalité (Paris: 10/18, 1963). Similarly, in Rousseau, Du contrat social (Oxford: Clarendon Press, 1972), he wrote: 'Pour autoriser un droit de première occupation, il faut quon en prenne possession non par une vaine cérémonie, mais par le travail et la culture' [to authorise a right to first occupation, you have to take possession not through formal ceremony, but through work and cultivation (Author's translation)]. 
Similarly, Kant saw the origins of statehood in the conflict between agriculturists and nomads and argued for the establishment of a proper agricultural society as the only way towards perpetual peace. In referring to aboriginal societies in America, Kant described the social organisation of nomadic peoples as lawless societies based on hunting, fishing and herding which of 'all forms of life ... is without doubt most contrary to a civilized constitution.' ${ }^{24}$ Kant saw the establishment of commerce and agriculture as the only way to bring peace to these 'uncivilised' places and the only path for humanity to achieve moral progress.

Overall, the crux of the 'agricultural argument' developed by the different philosophers and political scientists of the 18th century was that settlement and cultivation was the only basis for title to property. Thus, as nomadic groups did not improve the soil by cultivating it, 'they did not assert exclusivity; therefore, ... their rights were so negligibly thin as to disintegrate automatically wherever the European invader set literal or constructive foot. ${ }^{, 25}$ The principal rationale behind such an argument was that nomadic peoples were regarded to be in a sort of pre-political state of nature with no proper laws and institutions dealing with property in land. Despite some nomadic communities having extremely elaborate systems of property rights, ${ }^{26}$ political scientists and lawyers have usually failed to recognise such systems either by ignorance or by arrogance. Only a system based on settled agriculture was seen as giving rise to a recognised system of property in land.

This 'agricultural argument' had a deep impact on the development of international law. Vattel, who is considered one of the fathers of international law, stated that the cultivation of the soil ... is . . . an obligation imposed upon man by nature. ${ }^{27}$ Consequently, he affirmed that non-agricultural societies 'can not populate the whole country' as their occupancy cannot be 'a real and lawful taking of possession. ${ }^{28}$ Therefore, it was entirely lawful to occupy such a country. ${ }^{29}$ In relation to the colonisation of North America, Vattel wrote that Indian tribes:

can not take to themselves more land than they have need of or can inhabit and cultivate. Their uncertain occupancy of these vast regions can not be held as a real and lawful taking of possession; and when the

24 Kant, Perpetual Peace and Other Essays (Indianapolis: Hackett Publishing Company, 1983) at 122.

25 Bell, 'Forum on R. Marshall: Was Amerindian Dispossession Lawful? The Response of 19th Century Maritime Intellectuals', (2000) 23 Dalhousie Law Journal 168 at 179.

26 Ingold et al., Hunters and Gatherers: Property, Power and Ideology, Volume 2, supra n. 12.

27 Vattel, Le droit des gens, ou principes de la loi naturelle (1758), reprinted as The Law of Nations or the Principles of Natural Law (Washington: Carnegie Institute, 1916) at 37.

28 Ibid. at 85.

29 See Fitzpatrick, 'Terminal Legality: Imperialism and the (de)Composition of Law', in Kirkby and Coleborne (eds), Law, History, Colonialism, The Reach of Empire (Manchester: Manchester University Press, 2001) 14. 
Nations of Europe, which are too confined at home, come upon lands which the savages have no special need of and are making no present and continuous use of, they may lawfully take possession of them and establish colonies in them. ${ }^{30}$

Vattel's idea of the superiority of settled agricultural societies was a reflection of the general literature of this period. ${ }^{31}$ These 18th century theories fostered the idea that land ownership could only be based on the definite occupancy of such land and that agriculture was the only means to define the terms of occupation. The agricultural argument had a crucial impact on nomadic peoples' rights within the Law of Nations; it justified the colonisation of non-agricultural lands, and carried the idea that a community cannot be considered as sovereign if such a community is not composed of settled inhabitants with a so-called 'proper' land tenure system. The agricultural argument implied that sovereign nation-states can only be defined on the basis of a definite territory, a requirement which excludes nomadic tribes from the sphere of international law. As Lawrence stated in 1895: 'even if we suppose a nomadic tribe to have attained the requisite degree of civilization its lack of territorial organization would be amply sufficient to exclude it from the pale of International Law. ${ }^{32}$

Similarly, at the national level, the rules governing land tenure usually reflected the idea that nomadic peoples were not 'properly' using the land. ${ }^{33}$ Indeed, Burke has pointed out that the common law principle of adverse possession is also deeply embedded in the Western notion that occupation of the land is synonymous with the efficient use of the land: 'one justification for this doctrine is that it promotes the efficient use of land through punishment for non-use. ${ }^{, 34}$ This approach was based on the idea that nomadic peoples might exist, but that, based on their 'inferiority' and their non-rational uses of the lands, settlers have a right to own their lands. This theory prevailed in North America. For example, in the case of Johnson $v$ M'Intosh of 1823 the US Supreme Court stated:

The character and religion of [the New World's] inhabitants afforded an apology for considering them as a people over whom the superior genius of Europe might claim ascendancy. To leave them in possession of their country was to leave the country a wilderness.... Agriculturalists, merchants, and manufacturers, have a right, on

30 Vattel, supra n. 27 at 85.

31 One of the only exceptions being Wolff, Jus Gentium Methodo Scientifica Pertractum (1764) (Oxford: Clarendon Press, 1934), who held that single families and nomadic tribes had a right to the land they inhabited.

32 Lawrence, The Principles of International Law (London: MacMillan and Co., 1914) at 59.

33 See, for example, Goguet, De lorigine des lois, des arts, et des sciences, et leur progrès chez les anciens peuples (Paris: Chez Desaint and Saillant, 1758).

34 Burke, 'Let Out in the Cold: The Problem with Aboriginal Title under Section 35(1) of the Constitution Act, 1982 for Historically Nomadic Aboriginal Peoples', (2000) 38 Osgoode Hall Law Journal 1 at 29 , n. 80. 
abstract principles, to expel hunters from their territory .... Excuse, if not justification, [could be found] in the character and habits of the people whose rights had been wrested from them.... The potentates of the Old World... made ample compensation to the inhabitants of the new, by bestowing upon them civilization and Christianity. ${ }^{35}$

As a result of this theory of 'effective occupation' of lands, nomadic peoples have been regarded as legally non-existent. They were perceived as not being 'civilised' enough to have a right to occupy their lands. In relation to the rules governing title to territory the 'agricultural argument' resulted in the belief that territories inhabited by nomadic peoples were empty and open to conquest or discovery.

\section{B. 'Vacant' Territories: Nomadism as a Terra Nullius}

Under international law states can occupy any empty territory. This rule comes from the Roman law principle of terra nullius, meaning that any uninhabited territory is open to conquest and can be occupied by states. ${ }^{36}$ This principle has been extensively used by colonial powers in relation to nomadic peoples' territories, which were regarded as belonging to no one and open to colonisation. The 'agricultural argument' coupled with the concept of terra nullius meant that the use and occupation of territories by nomadic peoples had no standing, did not need to be respected and could not constitute a source for ownership or use of the land. It was only in 1975, in the Western Sahara case, ${ }^{37}$ that the relationship of nomadic peoples to their territories was recognised in international law. In this case, the UN General Assembly asked the International Court of Justice (ICJ) for an advisory opinion on the territorial dispute between Mauritania and Morocco regarding the status of the Western Sahara. One of the central issues for the ICJ was whether at the time of colonisation by Spain the Western Sahara was terra nullius. In exploring which of the two states (Mauritania or Morocco) had title to the territory, the ICJ considered whether the nomadic tribes that lived in the concerned area at the time of colonisation were to be regarded as occupiers of their lands or whether the territory was to be regarded as empty. The ICJ found that:

the nomadism of the great majority of the peoples of Western Sahara at the time of its colonization gave rise to certain ties of a legal character... The tribes, in their migrations, had grazing pastures,

35 Johnson $v$ M'Intosh 21 U.S. 543 at 573-90.

36 For a comprehensive overview of terra nullius, see Bedjaoui, Terra nullius, 'droits' historiques et autodétermination (The Hague: Sijthoff, 1975).

37 Advisory Opinion, ICJ Reports 1975, 12. 
cultivated lands, and wells or water-holes in both territories, and their burial grounds in one or other territory. These basic elements of nomads' way of life...were in some measure the subject of tribal rights, and their use was in general regulated by customs. ${ }^{38}$

The ICJ advised that nomadic tribes should be considered as having in the relevant period possessed rights, including some rights relating to the lands through which they migrated. ${ }^{39}$ The ICJ added that territories inhabited by nomadic peoples living as 'organised societies' were not to be considered empty nor open to state acquisition on the basis of occupation. In doing so, the ICJ rejected the application of an approach based on terra nullius by recognising that nomadic tribes had legal ties with their territories. Nevertheless, while the ICJ recognised these legal ties, the Court did not acknowledge that the nomadic peoples living in the Western Sahara had a legitimate claim to the territory. Instead, addressing the General Assembly's question, the ICJ tried to establish to which state the nomadic tribes had allegiance, so as to determine which state would exercise control over the territory of the Western Sahara. Even though this judgment can be seen as an important step towards the legal recognition of nomadic peoples' territorial entitlements, the ICJ did not consider nomadic peoples as potential owners of their territories. The Advisory Opinion can certainly be regarded as a crucial turning point in the relationship between nomadic societies and the rules governing title to territory as it recognised that nomadic peoples legally existed. However, the ICJ's opinion also highlighted that under international law nomadic societies are not to be regarded as exercising an effective occupation of their territories as only states could. Because this criteria of effective occupation is central to a claim to territorial sovereignty, international law seems to have no way of coping with nomadic peoples. The rules governing title to territory remain expressed within rigid territorial structures which do not consider a nomadic lifestyle as an effective mode of territorial possession.

The legal recognition of the existence of nomadic peoples and their ties to their traditional lands was echoed at the national level in a very significant decision of the High Court of Australia: Mabov Queensland (No. 2). ${ }^{40}$ This decision is significant both within Australia and internationally as Australia witnessed one of the most blatant applications of the terra nullius doctrine. During the process of colonisation of the continent, nomadic Aboriginal peoples were considered as having no legal rights and so their territories were subsequently perceived as 'empty' and open to colonisation. ${ }^{41}$ It was only in 1992 that the application of

38 Ibid. at para. 152.

39 Ibid.

40 (1992) 107 ALR 1.

41 See Reynolds, Aboriginal Sovereignty (Sydney: Allen and Unwin, 1996). 
the fiction of 'empty land' (terra nullius) was recognised as discriminatory and racist in essence. ${ }^{42}$ In the Mabo case, the Australian High Court relied on international law to reject the application of terra nullius in Australia, stating:

If the international law notion that inhabited land may be classified as terra nullius no longer commands general support, the doctrines of common law which depend on the notion that native peoples may be 'so low in the scale of social organization' that it is idle to impute to such people some shadow of the rights known to our law' can hardly be retained. $^{43}$

This quotation from the judgment of the High Court of Australia illustrates the crucial importance of the aforementioned ICJ Advisory Opinion that rejected the application of terra nullius to nomadic peoples. However, as pointed out above, despite this rejection of terra nullius the judgment did not open the right for nomadic peoples to claim territorial sovereignty; it merely recognised them as peoples capable of holding legal title to land.

The case between Chad and Libya over the Aouzou strip before the ICJ is also enlightening in understanding the international legal approach to nomadic peoples' rights over their own territory. ${ }^{44}$ In this case, Libya argued its title to the disputed territory based on its interaction with the Senoussi tribe, a nomadic group living on the disputed territory between Chad and Libya. However, the tribe had not been consulted. In a similar approach to the one adopted in the Western Sahara case, the parties referred to the nomadic tribes that live on the concerned territory only to provide evidence of their effective control over the territory. Thus, in this territorial dispute nomadic peoples were not considered to have any rights over their own territory. ${ }^{45}$

This position was reaffirmed in other international cases, including, for example, the case between Eritrea and Yemen before the Permanent Court of Arbitration. That Court held:

There can be no doubt that the concept of historic title has special resonance in situations that may exist even in the contemporary world, such as determining the sovereignty over nomadic lands occupied during time immemorial by given tribes who owed their allegiance to the ruler who extended his socio-political power over that geographic area. $^{46}$ 
This arbitral decision highlights the extent to which international law fails to consider the attachment of nomadic peoples to their territories as constituting a basis for title to territory. ${ }^{47}$

The different cases illustrate that despite the rejection of an unmitigated application of terra nullius to territories inhabited by nomadic peoples, international law still does not regard nomadic peoples as legal occupiers of their territories. This failure to recognise nomadic peoples as potential effective occupiers' of their lands is based on the diffuse but persistent belief that because nomadic peoples are continuously moving from place to place they do not really occupy the lands. The view that nomadic peoples and huntergatherers are not attached to any particular place has developed despite the work of modern anthropologists which proves how nomadic peoples have developed spiritual ties, and social and spatial boundaries to specific territories. ${ }^{48}$ While Deleuze and Guattari observe that no nomadic population wanders aimlessly and randomly, ${ }^{49}$ a key obstacle to recognition of title to territory lies in the fact that different sub-tribal groups often use the same territory in different ways and for different purposes. Yet, as Deleuze and Guattari also point out, the sharing of territories between nomadic groups and other groups (settled or nomadic) is done on the basis of very organised agreements; they refer to such sharing of territories as 'negotiated space' or 'distributional spaces, ${ }^{50}$ Evidence from both sociological and anthropological studies proves that for generations nomadic peoples have developed very strong ties with their territories, which are usually designated grazing, fishing or hunting areas. ${ }^{51}$ International law fails to recognise these ties as proof of effective occupation of territory. Only states can exercise a form of collective territorial ownership under their right to territorial sovereignty. In contrast, nomadic peoples are not recognised as effective occupiers; although one possible exception is that of nomadic peoples forming a state of their own. ${ }^{52}$

47 For an analysis of the decision see Reisman, "The Government of the State of Eritrea and the Government of the Republic of Yeman. Award of the Arbitral Tribunal in the First Stage of the Proceedings. (Territorial Sovereignty and Scope of the Dispute)', (1999) 93 American Journal of International Law 668.

48 See, for example, Casimir and Rao (eds), Mobility and Territoriality (New York: Berg, 1992).

49 Deleuze and Guattari, Mille Plateaux (Paris: Minuit, 1980) at 609.

50 Ibid. at 10.

51 For references, see generally Casimir and Rao, supra n. 48.

52 There is no state with a nomadic structure. The closest example is the case of the Western Sahara. In the past, Mongolia was often regarded as a 'nomadic' empire; however the contemporary status of the state does not make any specific recognition of nomadism. See Humphrey and Sneath, The End of Nomadism Society? Society, State and the Environment in Inner Asia (Durham: Duke University Press, 1999); Allsen, 'Sharing Out the Empire: Apportioned Lands Under the Mongols', in Khazanov and Wink (eds), Nomads in the Sedentary World (London: Curzon, 2001) 172; and Mearns, 'Community, Collective Action and Common Grazing: The Case of Post-Socialist Mongolia', (1996) 32 Journal of Development Studies 297. 
And as Jennings and Watts have highlighted: 'A wandering tribe, although it has a government and is otherwise organised, is a not a state until it has settled down in a territory of its own. ${ }^{53}$ In other words, nomadic peoples cannot exercise territorial sovereignty nor can they claim status as a state.

Public international law, and more particularly the rules governing title to territory, does not recognise any territorial rights for nomadic peoples, remaining constant in its approach that only a settled state can exercise territorial sovereignty. The criterion of statehood requiring that a state have a defined territory has not yet been read as possibly including the nomadic use of such territory, and nomadic peoples must fit into the structure of a state in which the majority is settled. As there are very few places in the world that have a predominately nomadic population that could potentially claim statehood and challenge the present understanding of territorial sovereignty, ${ }^{54}$ nomadic peoples must look beyond the rules governing title to territory to find ways that would allow them to claim rights over their traditional transient territories. Such an avenue has been developed for nomadic peoples under the banner of indigenous peoples' rights, under which international law has started to acknowledge that cultural ties to territory could be the source of rights over territories for indigenous peoples.

\section{Nomadic Peoples as Indigenous Peoples: Collective Land Rights}

Indigenous peoples' rights under international law have witnessed major developments in recent years. ${ }^{55}$ One of the cornerstones of indigenous peoples' rights is their right to use and/or own their traditional territories and, consequently, recent legal developments in indigenous peoples' rights could be used to support nomadic peoples' legal claims over their territories. Indeed, nomadic peoples have often resorted to the international mechanisms offered to indigenous peoples at the United Nations; for example, every year, several nomadic peoples' representatives attended the UN Working Group on Indigenous Populations.

A crucial issue when addressing the rights of nomadic peoples is their status under international law. Within international law there is no accepted legal definition of indigenous peoples. There are, however, three key legal

53 Jennings and Watts, Oppenheim's International Law, Volume I, 9th edn (London: Longman, 1992) at 563-4.

54 See Castellino, 'Territory and Identity in International Law: The Struggle for SelfDetermination in the Western Sahara', (1999) 28 Journal of International Studies 523.

55 See Thornberry, Indigenous Peoples and Human Rights (Manchester: Manchester University Press, 2002) and Anaya, Indigenous Peoples in International Law, 2nd edn (New York: Oxford University Press, 2004). 
definitions from the United Nations, the International Labour Organisation (ILO) and the World Bank which are often referred to. ${ }^{56}$ The first definition outlined by the UN Special Rapporteur Martinez Cobo is often accepted as authoritative. He defined indigenous peoples as follows:

Indigenous communities, peoples and nations are those which, having a historical continuity with pre-invasion and pre-colonial societies that developed on their territories, consider themselves distinct from other sectors of the societies now prevailing in those territories, or parts of them. They form at present non-dominant sectors of society and are determined to preserve, develop and transmit to future generations their ancestral territories, and their ethnic identity, as the basis of their continued existence as peoples, in accordance with their own cultural patterns, social institutions and legal systems. ${ }^{57}$

The second definition is taken from the ILO Convention No. 169 on Indigenous and Tribal Peoples. Article 1(1) defines indigenous peoples as:

...peoples in independent countries whose social, cultural and economic conditions distinguish them from other sections of the national community, and whose status is regulated wholly or partially by their own customs or traditions or by special laws or regulations; ... peoples in independent countries who are regarded as indigenous on account of their descent from the populations which inhabited the country, or a geographical region to which the country belongs, at the time of conquest or colonisation or the establishment of present state boundaries and who, irrespective of their legal status, retain some or all of their own social, economic, cultural and political institutions. ${ }^{58}$

The World Bank has adopted its own policy on indigenous peoples, which does not formally define the term 'indigenous peoples' but refers to groups with a distinct cultural and social background possessing the following characteristics in varying degrees:

(i) self-identification as members of a distinct indigenous cultural group and recognition of this identity by others;

(ii) collective attachment to geographically distinct habitats or ancestral territories in the project area and to the natural resources in these habitats and territories;

56 For example, see Makkonen, Identity, Difference and Otherness, The Concepts of 'Peoples', 'Indigenous People' and 'Minority' in International Law (Helsinki: Erik Castren Institute of International Law and Human Rights, 2000).

57 Martinez-Cobo, Study of the Problem of Discrimination Against Indigenous Populations, E/CN.4/ Sub.2/1986/7/Add.4 at para. 379.

58 Article 1(1), Convention No. 169 on Indigenous and Tribal Peoples 1989, 1650 UNTS 383. 
(iii) customary cultural, economic, social, or political institutions that are separate from those of the dominant society and culture; and

(iv) an indigenous language, often different from the official language of the country or region. ${ }^{59}$

Even though each is slightly different, these three definitions have certain common elements. They all offer a mix of objective' criteria, such as historical continuity, and 'subjective' ones, most commonly self-definition. In particular, three features are shared by all the definitions: (i) indigenous peoples are descendants of the original inhabitants of territories since colonised by foreigners ('having a historical continuity with pre-invasion and pre-colonial societies'); (ii) they have distinct cultures, which set them apart from the dominant society; and (iii) they have a strong sense of self-identity. Nomadic peoples could fulfil these criteria; they often have preceded the creation of the state in which they live and could be considered 'first peoples' ${ }^{60}$ and they have a close attachment to their ancestral territories through their commitment to a transhumant pastoralist culture and identity. The three definitions also highlight that indigenous peoples are communities who live in a non-dominant situation. Similarly, nomadic peoples often live marginalised from the dominant political and economic systems as a result of their non-agricultural economic base and traditional cultural identity. Thus, with reference to these criteria, the situation of nomadic peoples could correspond to the definition of indigenous peoples under international law and it is possible to refer to 'nomadic indigenous peoples'.

The recognition of nomadic peoples as indigenous peoples could have profound significance in relation to the recognition of their territorial rights. Under international law indigenous peoples have a specific right to a collective and customary form of land ownership and this could encompass a nomadic approach to land ownership and usage.

\section{A. Nomadic Indigenous Peoples' Right to Collective Land Usage and Ownership}

Many states do not acknowledge the right of nomadic peoples to exercise their traditional use of land. Most national legal systems do not recognise collective forms of land ownership and usage and several states have put in place policies transferring land from common grazing to private individual ownership. For example, during the three sub-regional seminars on 'Multiculturalism in Africa' organised by the United Nations, a major issue was the relationship

59 World Bank, 'Operational Policy and Bank Procedures on Indigenous Peoples', 10 May 2005, OP/BP 4.10.

60 However, see the debates regarding the Roma/Gypsies originating in northern India and now living in other continents: Henrard, 'The Building Blocks for an Emerging Regime for the Protection of a Controversial Case of Cultural Diversity: The Roma', (2003) 10 International Journal on Minority and Group Rights 183. 
between pastoral peoples and agriculturalists. Participants pointed out that the key issue in this relationship was the very specific conception of individual versus collective control over land and natural resources. ${ }^{61}$ Similarly, the African Commission on Human and Peoples' Rights' Working Group of Experts on Indigenous Populations/Communities has noted that 'the favouring of settled agriculture over hunting, gathering and nomadic cattle herding has been instrumental in both marginalizing and stigmatising some peoples and inspiring them to identify themselves as indigenous groups. ${ }^{62}$ By claiming their rights as indigenous peoples, nomadic peoples can assert their right to have their traditional forms of landholding recognised. In doing so, nomadic peoples can claim their right to maintain their nomadic lifestyle and their specific attachment to their territories as being part of their traditional way of life. A right for nomadic peoples to maintain their traditional nomadic way of life is crucial to modelling their cultural and property rights.

Regarding the right of indigenous peoples over their traditional territories, the only specific internationally binding legal instrument is ILO Convention No. 169. This convention is also the only international human rights-oriented treaty which specifically addresses the situation of nomadic peoples. In particular, Article 14 on land ownership provides that "particular attention shall be paid to the situation of nomadic peoples and shifting cultivators' ${ }^{63}$ The specific focus on the situation of nomadic indigenous peoples is the result of a long series of debates and discussion within the ILO. Indeed, it is worth noting that the ILO Convention No. 107 on Indigenous and Tribal Populations 1957 (ILO Convention No. 107), ${ }^{64}$ which was the predecessor to ILO Convention No. 169, does not specifically mention the situation of nomadic peoples. ILO Recommendation 104 concerning the Protection and Integration of Indigenous and Other Tribal and Semi-Tribal Populations in Independent Countries, ${ }^{65}$ which was adopted as a supplement to ILO Convention No. 107, mentions the specific situation

61 See Report of the Seminar on Multiculturalism in Africa: Peaceful and Constructive Group Accomodation in Situations Involving Minorities and Indigenous Peoples, Arusha, United Republic of Tanzania, 13-15 May 2000, 18 May 2000, E/CN.4/Sub.2/AC.5/2000/WP.3; Report on the Second Workshop on Multiculturalism in Africa: Peaceful and Constructive Group Accommodation in Situations Involving Minorities and Indigenous Peoples, Kidal, Mali, 8-13 January 2001, 2 April 2001, E/CN.4/Sub.2/AC.5/2001/3; and Report on the Third Workshop on Multiculturalism in Africa: Peaceful and Constructive Group Accommodation in Situations Involving Minorities and Indigenous Peoples, Gabarone, 18-22 February 2002, 17 June 2002, E/CN.4/Sub.2/AC.4/2002/4.

62 Report of the African Commission's Working Group of Experts on Indigenous Populations/ Communities, 14 May 2003 at 92.

63 Article 14, ILO Convention No. 169.

64 ILO Convention No. 107 Concerning the Protection and Integration of Indigenous and Other Tribal and Semi-tribal Populations in Independent Countries, 1328 UNTS 247. This Convention is no longer open for ratification but it is still in force for 18 states.

65 ILO Recommendation 104 concerning the protection and integration of indigenous and other tribal and semi-tribal populations in independent countries, 5 June 1957. The term 'semi-tribal' refers to 'persons who, although they are in the process of losing their tribal characteristics, are not yet integrated into the national community'. 
of nomadic peoples. However, the approach taken in the recommendation was still deep-rooted within the integrationist approach of the late 1950s:

(1) The population concerned should be assured of a land reserve adequate for the needs of shifting cultivation so long as no better system of cultivation can be introduced.

(2) Pending the attainment of the objectives of a settlement policy for semi-nomadic, zones should be established within which livestock of such groups can graze without hindrance. ${ }^{66}$

The specific reference to nomadic peoples in ILO Convention No. 169 came as an answer to criticisms of the integrationist objectives of ILO Convention No. 107 and of ILO Recommendation $104 .^{67}$ The first draft of the revised ILO Convention No. 107 did not mention nomadic peoples. ${ }^{68}$ However, the Meeting of Experts, which was in charge of drafting the new convention, noted the need to address the specific situation of nomadic peoples; a position based on the recognition that in many states national policies had been adopted to settle nomadic indigenous peoples. ${ }^{69}$ The Experts highlighted that if programmes to settle indigenous and tribal peoples occur in situations where competing claims are being made to their traditional lands by outside colonists or developers, there is danger that these peoples may be compelled to change their lifestyles and lose effective access to their traditional lands. ${ }^{, 70}$ This approach opened the door to further consideration of the position of nomadic peoples in the drafting of ILO Convention No. 169 and there was a strong focus on the specific situation of nomadic peoples as regard their right to use their traditional territories during the drafting debates. ${ }^{71}$ The text that was finally adopted provides:

The rights of ownership and possession of the peoples concerned over the lands which they traditionally occupy shall be recognised. In addition, measures shall be taken in appropriate cases to safeguard the right of the peoples concerned to use lands not exclusively occupied by them, but to which they have traditionally had access for their subsistence and traditional activities. Particular attention shall be paid to the situation of nomadic peoples and shifting cultivators in this respect. ${ }^{72}$

66 [emphasis added].

67 See Barsh, 'Revision of ILO Convention No. 107', (1987) 81 American Journal of International Law 756.

68 International Labour Conference, Partial Revision of the Indigenous and Tribal Populations Convention, 1957 (No. 107), 75th Session, Report IV (1), 1987 at 9.

69 Ibid. at $65-6$.

70 Ibid.

71 International Labour Conference, Partial Revision of the Indigenous and Tribal Populations Convention, 1957 (No. 107), 76th Session, Report IV (2B), 1989 at 14.

72 Article 14, ILO Convention No. 169. 
Article 14 makes a clear distinction between peoples that traditionally occupied lands and consequently have a right of ownership, and peoples who are using lands that are not exclusively occupied by them that have a right to use the land. It seems clear that nomadic peoples, who are seen as sharing land, would have a right to use rather than own lands. ${ }^{73}$ This right for nomadic peoples to use lands is a welcome development within international law, and in this regard ILO Convention No. 169 stands as the leading treaty on the issue; the only limit to its benefit being that to date only 19 states have ratified the convention. ${ }^{74}$

The International Covenant on Civil and Political Rights $1966^{75}$ (ICCPR) also provides protection for indigenous peoples' land rights. It is a significant instrument in nomadic peoples' quest toward territorial rights as it is a much more widely ratified instrument than ILO Convention No. 169. Article 27 which protects minority rights has been interpreted by the Human Rights Committee (HRC) to extend to protecting indigenous peoples' specific relationship with their territories. In its General Comment No. 23 on Article 27 the HRC stated:

With regard to the exercise of the cultural rights protected under article 27, the Committee observes that culture manifests itself in many forms, including a particular way of life associated with the use of land resources, especially in the case of indigenous peoples. That right may include such traditional activities as fishing or hunting and the right to live in reserves protected by law. ${ }^{76}$

The reference to 'a particular way of life associated with the use of land resources' makes Article 27 especially relevant to the situation of nomadic peoples as it embraces the right for nomadic peoples to exercise their specific use of natural resources. From this perspective, Article 27 must be understood as protecting the right for nomadic peoples to maintain their traditional lifestyle and use of natural resources. Relying on this approach, the HRC has developed a significant jurisprudence based on Article 27 of the ICCPR. ${ }^{77}$

An important aspect of this jurisprudence relates to the adaptation of nomadic peoples' way of life to modern technologies. For example, one of the crucial

73 For a discussion on this issue, see, for example: ILO-ITP Project, 'Strengthening the Participation of Pastoralists and Hunter-Gatherers in the Kenya Constitution Review Process', November 2001, available at: www.ilo.org.

74 These are Argentina, Bolivia, Brazil, Colombia, Costa Rica, Denmark, Dominica, Ecuador, Fiji, Guatemala, Honduras, Mexico, Nepal, Netherlands, Norway, Paraguay, Peru, Spain and the Bolivarian Republic of Venezuela.

75999 UNTS 171.

76 Para. 7, General Comment No. 23: Article 27 (Rights of Minorities), HRI/GEN/1/Rev.7 at 158; 1-3 IHRR 1 (1994).

77 See Scheinin, 'The Right to Enjoy a Distinct Culture: Indigenous and Competing Uses of Land', in Orlin et al. (eds), The Jurisprudence of Human Rights: A Comparative Interpretive Approach (Turku: Åbo Akademi University Institute for Human Rights, 2000) at 159. 
issues for the HRC was to determine whether the adoption of modern techniques for reindeer herding activities could still qualify as a traditional form of land usage. This issue is central to the evolution of the HRC's approach to nomadic peoples' land rights as the protection of their right to use the land is encompassed within the right of indigenous peoples to exercise a traditional cultural way of life which is different from the main society in which they live. The key determination to be made is what constitutes traditional use of a territory; in many cases nomadic peoples have adapted their lifestyle to modern technology (for example, nomadic or semi-nomadic Inuits hunters of the Arctic are using helicopters for hunting and herding activities). This cultural approach to land rights for nomadic peoples has been tested numerous times through the individual complaints mechanisms of the HRC, which has received several individual complaints from Sami nomadic peoples. ${ }^{78}$ In Sara $v$ Finland the respondent state argued that the reindeer breeders of Sami origin were not entitled to the protection of Article 27 as they were using modern technology such as snow scooters and modern slaughterhouses and that the concept of culture in the sense of Article 27 provides for a certain degree of protection of traditional means of livelihood' to which the authors of the complaints were not entitled as they were using modern technology. ${ }^{79}$ On this issue the HRC stated:

While Finnish Sami have not been able to maintain all traditional methods of reindeer herding, their practice still is a distinct Sami form of reindeer herding, carried out in community with other members of the group and under circumstances prescribed by the natural habitat. Snow scooters have not destroyed this form of nomadic reindeer herding. 80

In this case, the fact that Finnish Sami were using snow scooters did not prevent them from claiming their right to use their lands in a traditional nomadic way, and thus to be entitled to the protection of their right to maintain such a lifestyle under Article 27 of the ICCPR.

This case is not isolated and the HRC has re-affirmed that nomadic peoples may adjust to modern life without losing their cultural rights in other cases. ${ }^{81}$ Overall, Article 27 of the ICCPR offers protection to nomadic peoples under the banner of minority rights, and in particular, the right to enjoy their culture.

78 See Länsman et al. v Finland (511/1992), CCPR/C/52/D/511/1992 (1994); 2 IHRR 287 (1995); Länsman et al. v Finland (671/1995), CCPR/C/58/D/671/1995 (1996); 4 IHRR 405 (1997); and Kitok $v$ Sweden (197/1985), CCPR/C/33/D/197/1985 (1988).

79 Sara et al. v Finland (431/1990), CCPR/C/50/D/431/1990 (1994); 1-3 IHRR 14 (1993) at para. 6.4.

80 Ibid. at para. 7.4 .

81 Länsman et al. v Finland (511/1992), supra n. 78; Kitok v Sweden, supra n. 78; and Lubicon Lake Band v Canada (167/1984), CCPR/C/38/D/167/1984 (1990). 
Of particular relevance to nomadic peoples is the fact that 'culture' may consist of a way of life which is closely associated with territory and use of its resources. This reference to a way of life closely associated with territory is crucial. For example, in the case of Diergaardt v Namibia, the HRC rejected the claim for Article 27 protection from a pastoralist community that had only a limited historical connection with their territory, stressing that such protection only applies to communities that can prove that their way of life is historically associated with their territories. ${ }^{82}$ Clearly, Article 27 will cover nomadic peoples' right to land to the extent that they can prove a historical cultural attachment to their lands.

The most pertinent jurisprudence related to the rights of nomadic indigenous peoples over their territories comes from the Inter-American system of human rights. The Inter-American Commission on Human Rights (IACommHR) has observed that land rights for indigenous peoples are essential for their survival as they represent a necessary way of providing them with the resources that sustain life and the geographic space necessary for the cultural and social reproduction of the group', 83

In its 2001 landmark decision in the case of Mayagna (Sumo) Awas Tingni Community $v$ Nicaragua, ${ }^{84}$ the Inter-American Court of Human Rights (IACtHR) affirmed the right of the indigenous community to collective ownership of their lands and natural resources. Important consequences for nomadic peoples flow from this judgment particularly as it was pointed out that "one of the grounds of the State for denying possession rights to the territory has been to argue that these communities are nomadic. ${ }^{85}$ The crucial issue for the IACtHR was that the indigenous community's relationship with their territories was based on a collective approach to ownership and sharing. As Stavenhagen, one of the expert witnesses, stated during the trial:

In lowlands, indigenous peoples have traditionally practiced shifting subsistence agriculture, especially in tropical forests. They often combine this shifting subsistence agriculture with other activities which require an economic space relatively larger than the specifically agricultural plot. The space in which the indigenous population moves, sometimes almost as semi-nomadic groups, is a collective space. ${ }^{86}$

Diergaardt et al. v Namibia (760/1997), CCPR/C/69/D/760/1997 (2000); 8 IHRR 46 (2001) at para. 10.6.

83 Report on the Situation of Human Rights in Ecuador, 24 April 1997, Ser.L/V/II.96.Doc.10 Rev 1 at 115.

84 Mayagna (Sumo) Awas Tingni Community v Nicaragua IACtHR Series C 79 (2001); 10 IHRR 758 (2003). See Pasqualucci, 'The Evolution of Indigenous Rights in the Inter-American Human Rights System, (2006) 6 Human Rights Law Review 281.

85 Testimony of Galio Enrique Gurdián Gurdiánm reproduced in the judgment, ibid.

86 Ibid. at para. $83 \mathrm{~d}$. 
It is through this prism of a right to a 'collective space' that the IACtHR recognised that the nomadic community had a right to the collective ownership and use of their traditional territories. The IACtHR stated:

Among indigenous peoples there is a communitarian tradition regarding a communal form of collective property of the land, in the sense that ownership of the land is not centred on an individual but rather on the group and its community. Indigenous groups, by the fact of their very existence, have the right to live freely in their own territory; the close ties of indigenous people with the land must be recognized and understood as the fundamental basis of their cultures, their spiritual life, their integrity, and their economic survival. For indigenous communities, relations to the land are not merely a matter of possession and production but a material and spiritual element which they must fully enjoy, even to preserve their cultural legacy and transmit it to future generations. $^{87}$

The IACtHR added that the respondent state should take into consideration indigenous peoples' customary law when recognising indigenous peoples' rights over their traditional territories. Thus, states must recognise property rights to land and natural resources based on traditional patterns of use and occupation of ancestral territory by indigenous peoples and nomadic peoples' traditional use of a territory should be regarded as a source of title to territory. It is important to underline that in its decision the IACtHR relied on 'an evolutionary interpretation of international instruments for the protection of human rights' discerning that under the current international regime of human rights protection there is an evolution towards such recognition. This is significant and highlights that the evolution towards a right to property which includes traditional forms of indigenous ownership is not limited to the Americas but is part of a universal advancement in human rights law. This is confirmed by recent developments at the national level regarding the rights of nomadic indigenous peoples through the development of a theory of native or aboriginal title.

\section{B. Aboriginal and Native Title Theories and Nomadic Peoples}

There has been some important progress at the national level regarding the right of indigenous peoples to exercise collective ownership over their traditional territories through the development of the theory of 'aboriginal' or 'native' title. ${ }^{88}$ Developed by national courts, this theory recognises indigenous peoples' land rights as rights existing through indigenous customary laws which pre-date

87 Ibid. at para. 149.

88 'Aboriginal' title is the terminology used in Canada whereas Australian jurisdictions refer to 'native' title. See McNeil, Common Law Aboriginal Title (Oxford: Clarendon Press, 1989). 
national legal systems. ${ }^{89}$ Even though the theory was developed mainly through Canadian and Australian jurisprudence, ${ }^{90}$ its use has gradually become more international and several common law courts have referred to it when dealing with indigenous peoples' land rights. ${ }^{91}$ Under the theory of aboriginal or native title, national courts have recognised that indigenous peoples do have rights over their territories which are based on their traditional customary systems of land usage. For nomadic peoples the development of such theory represents a positive step as it means the legal recognition of both their traditional customary laws on land usage and their itinerant way of life.

In exploring the common law application of the criteria for occupation to nomadic peoples, McNeil has arrived at the conclusion that there can be little doubt that a group of hunter-gatherers who habitually and exclusively ranged over a definite tract of land, visiting religious sites and exploring natural resources in accordance with their own interest and way of life, would have been in occupation of that land. ${ }^{92}$ As he points out, modern anthropological research has revealed that nomadic groups are not indiscriminate wanderers but are attached and bound to a specific territory. Thus, in relation to the rights of nomadic groups over their territories, McNeil argues:

the extent of their occupation, ... would include not just land in actual use by them at any given moment, but all land within their habitual range, for occupation, once acquired, is not necessarily lost by temporary absence, so long as the intention and capacity to retain exclusive control and return to the land continue, and no one occupies it in the meantime. ${ }^{93}$

One of the difficulties of applying aboriginal or native title theory to the situation of nomadic peoples is that an important criterion for proving the existence of a right of an indigenous community to its lands is to prove that they occupy

89 See, for example, the judgment of the Supreme Court of Canada (SCC), Delgamuukw v British Columbia (1997) 3 SCR 1010; and Dick, "Comprehending "the genius of the common law" Native Title in Australia and Canada Compared Post-Delgamuukw', (1999) 5 Australian Journal of Human Rights 1.

90 See, for example, from Canada: Calder v Attorney-General of British Columbia (1973) 34 DLR (3d) 145; Hamlet of Baker Lake v Minister of Indian Affairs and Others (1979) 107 DLR (3d) 513; $R$ v Adams (1996) 138 DLR (4th) 657 (SCC); $R$ v Van der Peet (1996) 137 DLR (4th) 289 (SCC); and Delgamuukw and Others v British Columbia, ibid.; and from Australia: Mabo and Others, supra n. 40; and Members of the Yorta Yorta Aboriginal Community v Victoria [2002] HCA 58; 214 CLR 422.

91 For examples, see the decision of the Supreme Court of Appeal of South Africa in Richtersveld Community and Others v Alexkor Limited and the Government of the Republic of South Africa, Case No. 488/2001, 24 March 2003; and the decision of the Federal Court of Malaysia in Adong bin Kuwau v Kerajaan Negeri Johor [1997] 1 MLJ 418, [1998] 2 MLJ 158. See also Gilbert, 'Historical Indigenous Peoples' Land Claims: A Comparative and International Approach to the Common Law Doctrine on Indigenous Title', (2007) 56 International and Comparative Law Quarterly 583; and Bennett and Powell, Aboriginal Title in South Africa Revisited', (1999) 15 South African Journal of Human Rights 449.

92 McNeil, supra n. 88 at 202.

93 Ibid. at 204. 
the land in an exclusive manner. ${ }^{94}$ This could prove problematic in the case of nomadic peoples who usually share the land with other groups. However, the Assembly of First Nations in Canada has highlighted that 'exclusivity does not refer to the absence of other groups on the land, but rather "the intention and capacity to retain exclusive control". 95 Similarly, the jurisprudence of national courts demonstrates that the criteria of exclusivity should not be seen as limiting access to indigenous title for nomadic groups. In the Richtersveld Community case, the Supreme Court of Appeal of South Africa pointed out that 'a nomadic lifestyle is not inconsistent with the exclusive and effective right of occupation of land by indigenous peoples. ${ }^{96}$ The South African court added that even though the concerned indigenous community need 'not have occupied every bit of the subject land, and even if other indigenous peoples sometimes visited the territory, their exclusive beneficial occupation of the entire area was not affected. ${ }^{97}$ Thus, nomadic peoples would not have to be the sole occupier of a land to prove their ties to their territory.

Nomadic groups must prove that they have exercised sufficient ties to the land to claim a right over it. The Supreme Court of Canada, in the Delgamuukv case, has affirmed that proof of physical occupation could be established in a number of different ways such as construction of dwellings, hunting traps, etc. ${ }^{98}$ In the case of nomadic peoples the relevant criteria would be the regular use of wells or defined tracts of land for hunting or fishing. However, Burke has highlighted how the judgments from the Supreme Court of Canada have excluded some historically nomadic groups from the protection offered under section 35(1) of the Constitution Act 1982 (which recognises and affirms the rights of aboriginal peoples of Canada). ${ }^{99} \mathrm{He}$ points out that a close reading of the Delgamuukv decision, and in particular, the comments of Larmer CJC that:

Because aboriginal rights can vary with respect to their degree of connection with the land, some aboriginal groups may be unable to make out a claim to title, but will nevertheless possess ... site-specific rights to engage in particular activities....The fact that aboriginal peoples were non-sedentary, however...does not alter the fact that nomadic peoples survived through reliance on the land prior to contact with Europeans and, further, that many of the practices, customs and traditions of nomadic peoples that took place on the land were integral to their distinctive cultures ${ }^{100}$

94 Delgamuukw v British Columbia, supra n. 89 at para. 143.

95 Assembly of the First Nations, 'The Amicus Curiae Brief of the Assembly of First Nations', (2000) 22 Human Rights Quarterly at 580.

96 Richtersveld Community and Others, supra n. 91 at para. 23.

97 Ibid. at para. 24.

98 Delgamuukw v British Columbia, supra n. 89 at para. 149.

99 Burke, supra n. 34.

100 Delgamuukw v British Columbia, supra n. 89 at para. 139. 
suggest that seasonally-nomadic aboriginals 'may be unable to make out a claim to Aboriginal title.' ${ }^{101}$

As the application of such strict criteria would reject seasonally nomadic aboriginals, Burke proposes an approach based on the 'bundle of rights theory' under which 'if an Aboriginal group can prove a sufficient number of sitespecific rights upon a reasonably circumscribed parcel of land, the group will be able to claim Aboriginal title over at least some of that land. ${ }^{102}$ Following such an approach, nomadic communities may be able prove their rights to their traditional territories by providing evidence of a sufficient number of sitespecific rights. Thus, if a group is able to prove its attachment to a specific territory through different site-specific rights, this group would then prove its attachment to such territory, and thus gain recognition of its aboriginal title. However, this approach was rejected by the Canadian Supreme Court in the 2005 cases of Marshall and Bernard. ${ }^{103}$ The Court set out a very high threshold of proof for aboriginal title and this may rule out any possibility of nomadic communities claiming title to their traditional lands. ${ }^{104}$ Thus, while Canadian courts have generally become more willing to receive indigenous peoples' own proof of occupation of the land, ${ }^{105}$ this evolution seems to be limited when it comes to nomadic communities. Although the development of a legal theory on aboriginal or native title has some significant implications for indigenous peoples, its relevance for nomadic or semi-nomadic peoples has yet to be demonstrated.

Overall, under the banner of indigenous peoples' rights, nomadic peoples have gained some recognition of their rights to land. However, there are some serious limitations to such an evolution. First, the rights of indigenous peoples under international law are still underdeveloped, with ILO Convention No. 169 being the only specific binding instrument concerning indigenous peoples. Second, there are still some debates regarding the definition of indigenous peoples and it seems that several nomadic communities would not qualify as 'indigenous. ${ }^{106}$ Furthermore, as the reference to indigenous peoples' rights

101 Burke, supra n. 34 at 26.

102 Ibid. at 31.

$103 R$ v Marshall; $R$ v Bernard (SCC) [2005] 2 SCR 220, (2005) SCC 43.

104 See the comments of LeBel J in $R v$ Marshall, ibid. at para. 126: "nomadic life might have given rise to specific rights exercised at specific places or within identifiable territories, but never to a connection with the land itself in the absence of evidence of intensive and regular use of the land.'

105 See Borrows, 'Listening for a Change: The Courts and Oral Tradition', (2001) 39 Osgoode Hall Law Journal 1; and Cooter and Fikentscher, 'Indian Common Law: The Role of Custom in American Indian Tribal Courts', (1998) 46 American Journal of Comparative Law 509.

106 For example, nomadic or semi-nomadic Roma communities would not qualify as indigenous. See Henrard, 'The Building Blocks for an Emerging Regime for the Protection of a Controversial Case of Cultural Diversity: The Roma', (2004) 10 International Journal on Minority and Group Rights 183. 
remains a controversial issue in several African and Asian countries, a designation as indigenous might not be beneficial to nomadic peoples in these regions. ${ }^{107}$ Third, the gradual recognition of indigenous peoples' land rights at the national level has not produced a suitable framework for nomadic peoples, as a higher threshold of fixed territorial attachment must be proven for nomadic communities to benefit. Fourth, and most importantly, the present body of law regarding indigenous peoples does not seem to address the particular situation of nomadic peoples.

Current debates at the international level on the eventual adoption of an international declaration on the rights of indigenous peoples have omitted the specific situation of nomadic peoples' land rights. The text of the UN Declaration on the Rights of Indigenous Peoples does not provide any specific protection for nomadic peoples' land rights. ${ }^{108}$ The next part of the article explores to what extent there is a need for a legal approach which recognises specific rights for nomadic peoples.

\section{Special Rights for Nomadic Peoples: Towards a 'Nomadic Lex Specialis?}

A variety of factors, including environmental concerns, development, control of migration and restrictions to freedom of movement, are increasingly putting pressure on nomadic lifestyles. The next part of this article argues that to respond to these threats, there needs to be a legal arsenal that would allow nomadic peoples to perpetuate their specific nomadic use of the land. There are two sets of specific rights relevant to nomadic peoples: first, rights that are accessories to the nomadic way of life (such as hunting or gathering rights), and second, rights that relate to an enlarged approach to freedom of movement encompassing a nomadic way of life. The first set of rights are usufructuary rights attached to land and the rights to specific mobile services, whereas freedom of movement refers to rights such as the right to cross borders or to have access to halting sites.

107 See Kingsbury, 'Indigenous Peoples in International Law: A Constructivist Approach to the Asian Controversy', (1998) 29 American Journal of International Law 414; and Hitchcock, 'Human Rights and Indigenous Peoples in Africa and Asia', in Forsythe and McMahon (eds), Human Rights and Diversity: Area Studies Revisited (Lincoln: University of Nebraska Press, 2002) at 205.

108 The text of the UN Declaration on the Rights of Indigenous Peoples was adopted by the Human Rights Council on 29 June 2006, A/HRC/1/L.10, and by the UN General Assembly on 13 September 2007, GA/10612. See Gilbert, 'Indigenous Rights in the Making: The United Nations Declaration on the Rights of Indigenous Peoples', (2007) 14 International Journal on Minority and Group Rights 207. 


\section{A. Between Tradition and Modernity: Protecting Usufructuary Nomadic Rights and Providing Nomadic Services}

Often nomadic peoples continually move from one place to another because they live in harsh environments. ${ }^{109}$ Environmental pressures have led to the development of particular nomadic systems of survival, which rely on the specific use of natural resources. Based on their particular way of life, nomadic peoples have specific needs. Rights to hunt or graze could be, and often are, essential to survival. However, there is often a clash between states and nomadic peoples on this issue. The current trend of economic globalisation is giving rise to an increased need for primary natural resources and this has often had a direct impact on the lives of nomadic communities that dwell in territories rich in natural wealth. The control over natural resources and their exploitation is a significant area of on-going conflict between states, nomadic peoples and other private actors such transnational corporations. In this quest for natural resources, the nomadic way of life is regularly presented as destroying the natural environment. ${ }^{110}$ In very dry parts of Africa especially, pastoralists are viewed as the main agents of soil erosion and desertification-consequences of over-grazing and deforestation. Berger, in her research on the situation of pastoralist nomadic peoples' use of lands in Kenya, has argued that '[g]overnments and scientists have long regarded the pastoralists' way of life as a cause of environmental degradation. This belief is rooted in a misunderstanding of the pastoralist way of life and is reflected in national policies on land tenure and resource access in Kenya. ${ }^{111}$ Overall, and as pointed out by Campbell, in Africa, nomadic peoples' pastoralist access to lands has been "undermined by "scientific" rangeland conservation policies that rely on the "tragedy of the commons" thesis in which "common property rights" in land and natural resources are incorrectly linked to overgrazing and environmental degradation. ${ }^{, 112}$ Such false claims have had a tragic impact on nomadic peoples' lives: by invoking the idea that nomadic peoples are making the 'wrong' usage of lands, states and other agencies have tried to force nomadic peoples into a sedentarised way of life. ${ }^{113}$ Unfortunately, this trend is not limited

109 On this issue, see generally Casimir and Rao, supra n. 48.

110 Bjørklund, 'Sámi Reindeer Pastoralism as Indigenous Resource Management System in Northern Norway: A Contribution to the Common Property Debate', (1990) 21 Development and Change 75.

111 Berger, "Conflict Over Natural Resources Among Pastoralists in Northern Kenya: A Look at Recent Initiatives in Conflict Resolution', (2003) 15 Journal of International Development at 246.

112 Campbell, ‘Ethnic Minorities and Development’, (2004) 4 Ethnicities 5 at 12.

113 The African Commission's Working Group of Experts on Indigenous Populations/ Communities reported that "many African governments have tended to apply development paradigms focusing on assimilationist approaches designed to turn indigenous peoples into sedenterized crop cultivating farmers on the assumption that the ways of life of indigenous peoples have to change because they are 'primitive', 'backward,' 'unproductive' and degrading to the environment.' See Report of the African Commission's Working Group of Experts on Indigenous Populations/Communities, 22 April 2005. 
to Africa and across the world states, as well as international developmental agencies, have put in place policies of 'development' for nomadic peoples based on a so-called more rational use of the land, and forcing them to turn to agriculture. Thus, as Hitchcock noted in the case of the San in Southern Africa, a major concern of nomadic communities is 'whether or not they will be able to maintain their rights to hunting and gathering in the face of major changes in land and natural resource conservation legislation and development projects that tend to favour mining, agriculture, and commercial livestock production. ${ }^{114}$ This is why nomadic peoples' continued rights to hunt, fish and gather on their territories are vital rights to be protected.

A central component of nomadic peoples' property rights are usufructuary rights to land. For nomadic peoples these include rights to hunt, fish, graze and gather. These rights are at the core of many nomadic cultures which rely on hunting or gathering activities for their livelihoods. Around the world, many nomadic groups are witnessing an obfuscation of their usufructuary rights. As highlighted above, fishing or hunting is often seen as destructive of the natural environment. However, limitations on the rights of nomadic communities to perpetuate activities such as hunting are not new. Early in the development of a legal relationship between colonisers and aboriginal peoples in North America, the right to hunt was a contentious issue. The Royal Proclamation of 1763 which formalised the legal framework of the relationship between aboriginal peoples and the Crown in British North America paid specific attention to hunting rights. The Proclamation stated:

It is just and reasonable and essential to our Interest, and the Security of our Colonies, that several Nations or Tribes of Indians with whom We are connected, and who live under our Protection, should not be molested or disturbed in the Possession of such parts of Our Dominions or Territories as, not having been ceded to or purchased by Us, are reserved to them, as their Hunting grounds. ${ }^{115}$

Similarly the treaties that were signed between the Dominions of Canada and several aboriginal nations often focused on the recognition of hunting rights for aboriginal peoples. ${ }^{116}$ The rights proclaimed in treaties signed in the 18th or 19th centuries have had a considerable impact on the rights of first nations today. ${ }^{117}$

114 Hitchcock, "“Hunting is Our Heritage", The Struggle for Hunting and Gathering Rights among the San of Southern Africa', Paper presented at the 8th International Conference on Hunting and Gathering Societies, October 1998, Osaka, Japan.

115 The Royal Proclamation, reprinted in Kennedy (ed.), Documents of the Canadian Constitution, 1759-1915 (Toronto: Oxford University Press, 1918) at 20.

116 For example, see Treaty 3 between Her Majesty the Queen and the Saulteaux Tribe of the Ojibbeway Indians 1873, which provides: 'Her Majesty further agrees with her said Indians, that they, the said Indians, shall have the right to pursue their avocations of hunting and fishing throughout the tract surrendered.'

117 See Miller, 'Native Rights: Indians Hunting and Fishing Rights', (1991) 21 Environmental Law 1291. 
In terms of contemporary international law, hunting, fishing and gathering rights are part of the larger body of rights of minorities to exercise their own culture. It is mainly through the recent development of the rights of indigenous peoples over their traditional territories that international law has addressed the right for nomadic peoples to perpetuate usufructuary rights such as hunting or fishing. For example, ILO Convention No. 169 provides that the traditional activities of the peoples concerned, such as hunting, fishing, trapping and gathering, shall be recognised as important factors in the maintenance of their cultures and in their economic self-reliance and development. ${ }^{\text {,18 }}$ As mentioned earlier, the HRC in its General Comment on Article 27 of the ICCPR pointed out: 'Culture manifests itself in many forms, including a particular way of life associated with the use of land resources, especially in the case of indigenous peoples. That right may include such traditional activities as fishing or hunting and the right to live in reserves protected by law. ${ }^{119}$ As a result of such a broad approach to cultural rights for minorities, the HRC has developed a position which pays specific attention to the rights of nomadic or semi-nomadic groups to exercise their right to hunt or fish. For example, in its 2000 Concluding Observations to Australia, the HRC affirmed that the continuation and sustainability of traditional forms of economy for indigenous minorities such as hunting, fishing and gathering should be 'a major factor in determining land use. ${ }^{120}$ A similar approach regarding nomadic groups' right to exercise their hunting rights has been developed through the individual complaint mechanism of the HRC. In the case of the Lubicon Lake Band, ${ }^{121}$ the members of the aboriginal community who were the authors of the complaint argued that their nomadic way of life had been significantly altered by recent developments concerning the exploitation of oil in their territories which were destroying their traditional hunting and trapping territory. The HRC recognised that "the rights protected by article 27 , include the right of persons, in community with others, to engage in economic and social activities which are part of the culture of the community to which they belong. ${ }^{122}$ Furthermore, the HRC explicitly recognised that 'historical inequities, to which the State party refers, and certain more recent developments, threaten the way of life and culture of the Lubicon Lake Band, and constitute a violation of Article 27 so long as they continue. ${ }^{123}$ Thus, even though the concerned community was no longer living a nomadic lifestyle, the HRC took into consideration past restrictions to the hunting rights of the community as part of an 'ongoing violation' of their rights under Article 27 of the ICCPR. In broader terms, this decision highlights that the HRC has

Article 23(1), ILO Convention No. 169.

119 Human Rights Committee, supra n. 76 at para. 7.

120 Concluding Observations of the Human Rights Committee: Australia, 24 July 2000, A/55/40 at paras $498-528$.

121 Lubicon Lake Band, supra n. 81

122 Ibid. at para. 32.2.

123 Ibid. at para. 33. 
adopted an approach to cultural rights which includes a right to hunt for nomadic communities when such a right is seen as part of their traditional cultural patterns. $^{124}$

The HRC is not the only UN treaty monitoring body that has paid specific attention to usufructuary rights of nomadic peoples. The Committee on the Elimination of Racial Discrimination has commented on the rights to hunt and fish for Sami peoples in its 2001 recommendations to Sweden, and expressed its concern 'over the issue of land rights of the Sami people, in particular hunting and fishing rights which are threatened by, inter alia, the privatization of traditional Sami lands. ${ }^{125}$

At the regional level, the IACommHR has also addressed the issue of hunting rights. In the case of Mary and Carrie Dann v United States, ${ }^{126}$ the Danns and other members of the Western Shoshone nation alleged that they had been obstructed in carrying out their traditional subsistence hunting by state officials who refused to accommodate traditional Western Shoshone hunting practices. The petitioners claimed that '[s] tate officials have sought out and arrested members of the Western Shoshone people including members of the Dann band who do not comply with the state hunting laws and regulations. ${ }^{, 27}$ The IACommHR pointed out that under the American Declaration on the Rights and Duties of Man there is a duty to take 'special measures to ensure recognition of the particular and collective interest that indigenous people have in the occupation and use of their traditional lands and resources and their right not to be deprived of this interest except with fully informed consent, under conditions of equality, and with fair compensation., ${ }^{28}$

The development of a specific approach towards nomadic peoples' usufructuray rights is not limited to human rights bodies. The World Bank has also paid attention to these rights. The World Bank's Operational Directive on Involuntary Resettlement, which sets out requirements to minimise the effects of resettlement caused by development projects financed by the World Bank, mentions the situation of nomadic peoples and specifically protects "pastoralists who may have usufruct or customary rights to the land or other resources taken for the project. ${ }^{129}$

In conclusion, it seems that gradually human rights treaty bodies, regional human rights bodies and development agencies such as the World Bank are recognising the need to recognise specific usufructuary rights of nomadic

124 See also the HRC's decision in see Jonassen et al. v Norway (942/2000), CCPR/C/76/D/881/ 1999 (2002); 10 IHRR 323 (2003), which examines grazing rights.

125 Concluding Observations of the Committee on the Elimination of Racial Discrimination: Sweden, 1 May 2001, CERD/C/304/Add.103 at para. 13.

126 Case 11.140, Mary and Carrie Dann v United States Report No. 75/02 (2002); 10 IHRR 1143 (2003).

127 Ibid. at para. 41.

128 Ibid. at para. 131.

129 World Bank Operational Manual, 'Involuntary Resettlement', June 1990, OD 4.30. 
peoples. Yet, the development of a body of law which protects the usufructuary rights of nomadic peoples is still in its infancy, as there are no specific international human rights instruments which address these rights. As highlighted earlier there is a clear need for states and development agencies to recognise usufructuary rights and for human rights treaty bodies to continue to pay specific attention to the fragile and ancestral right of nomadic peoples to maintain their traditional use of their lands through the perpetuation of their usufructuary rights.

\section{B. Freedom of Movement: Cross Border Rights and Ensuring Halting Facilities}

Nomadism is about moving freely. It seems logical, therefore, that a central way to protect an eventual right to nomadism would come under the banner of a right to freedom of movement. Two issues particularly affect nomadic peoples' freedom of movement. First, the ability to move freely across the borders of different states; and second, the right to a halting site, or a right to encampment.

In recent years, many nomadic peoples have been restricted in their cross-border movements. By definition nomadic peoples are peoples on the move or mobile peoples. This free movement runs contrary to the will of states to control the movement of peoples across borders. The establishment of modern national boundaries with strong border surveillance often limits nomadism. As Krakover has stated: 'the demarcation of boundaries and the creations of states put a heavy strain on the nomad way of life. ${ }^{130}$ Such a clash is not only a contemporary issue: since European colonisers have established borders all over the world this has created difficulties for nomadic peoples whose traditional way of life finds themselves crossing the borders of different countries. As Menon has noted:

Nomadic peoples principally engaged in hunting and watching over their grazing flocks had little, if any, conception of a boundary as definite line of demarcation. Only with the development of agriculture and a settled population did the idea of proprietary rights in land, and consequently the need for precise boundary line rather than broad intervening zones, begin to develop. ${ }^{131}$

Furthermore, the anthropologist Brody has highlighted that frontiers were celebrated for the opportunities they offered to settlers and adventurers,

130 Krakover, 'Urban Settlement Program and Land Dispute Resolution: The State of Israel Versus the Negev Bedouin', (1999) 47 GeoJournal 551.

131 Menon, 'International Boundaries - A Case Study of the Guyana-Surinam Boundary', (1978) 27 International and Comparative Law Quarterly 738 at 740 . However, he notes that there were a few exceptions, for example, the Boro people of the west Amazon, the Maidu of California and the Vedda of Ceylon. 
whilst the nomads knew no borders; they used to freely cross regions that are nowadays caught between different national borders. ${ }^{132}$ Despite the historical disregard for nomadic peoples' movement across borders, there have been a few exceptions where the issue of cross border rights for nomads has been a central issue in the establishment of borders. For example, when the NorwegianSwedish border was defined by the Stromstad Treaty of 1751, specific attention was given to the rights to cross the borders for the nomadic tribes living on either side of the border. An addendum to the Stromstad Treaty, also known as "the Lapp Kodicill', recognised the right of the Sami to freely cross the border as part of their seasonal migration of reindeer herding:

The Sami need the land of both states. Therefore, they shall, in accordance with tradition, be permitted both in autumn and spring to move their reindeer herds across the border into the other state. And hereafter, as before, they shall, like the state's own subjects, be allowed to use land and share for themselves and their animals, except in the places stated below, and they shall be met with friendliness, protected and aided. ${ }^{133}$

Likewise, Annex 3 of the 1897 treaty between Britain and Ethiopia, regarding control over the Ogaden region along the Ethiopian-Somali border, reserved grazing rights for nomadic tribes across the border. ${ }^{134}$ More recently, Article 9 of the Convention of Good Neighbourliness 1955, between France and Libya, recognised the rights for nomadic tribes to freely cross borders: 'The Government of France and the Government of Libya undertake to grant freedom of movement to nomads from tribes that traditionally trade on either side of the frontier.' ${ }^{135}$ These treaties highlight that the possibility for nomadic peoples to cross borders allowing them to perpetuate their ancestral migration movement has been a recognised privilege.

The entitlement to cross borders remains a contemporary issue for nomadic peoples who live between different countries. ILO Recommendation 104 addresses the situation of indigenous nomadic communities who live in frontier zones and recommends that governments take intergovernmental action . . by means of agreements between the governments concerned, to protect seminomadic tribal groups whose traditional territories lie across international boundaries' and to ensure members of these groups receive fair wages for work

132 See Brody, The Other Side of Eden, Hunter-Gatherers, Farmers and the Shaping of the World (London: Faber and Faber Ltd, 2001).

133 As quoted in Sillanpää, Impact of International Law on Indigenous Rights in Northern Europe (Ottawa: Indian and Northern Affairs Canada, 1992) at 6.

134 East, 'Ethiopia-Somalia', in Day (ed.), Border and Territorial Disputes, 2nd edn (Harlow: Longman, 1987) at 114-6.

135 As quoted by the International Court of Justice in Territorial Dispute (Libya $v$ Chad), supra n. 44 at para. 53. For the historical background to this treaty, see Dadi, 'Mémoire du Gouvernement de la République du Tchad, Chapitre III', ibid. 
done and are not subject to discrimination. ${ }^{136}$ However, despite these indications of a specific entitlement to cross-border rights for nomadic peoples, such a right remains extremely limited under international law, particularly with the drive towards restricting cross-border movement. This issue is not well addressed under international law and deserves more attention. The development of a specific right for nomadic peoples to travel across national borders during seasonal migrations is crucial for their survival. After all, a boundary is 'the imaginary line which divides two pieces of land from one another, ${ }^{137}$ and international law should acknowledge that for nomadic peoples there should be a special right to cross these imaginary lines.

As stated earlier, a second aspect of freedom of movement for nomadic peoples relates to their right to use halting sites. Often the movement of nomadic peoples is restricted by rules prohibiting them from halting and setting up camp. Europe, particularly, has seen an increasing tendency to restrict the possibility for nomadic or semi-nomadic groups such as the Travellers ${ }^{138}$ or the Roma to do so. ${ }^{139}$ Accordingly, one of the most developed legal theories relating to halting or transient sites comes from Europe. The Council of Europe especially has paid attention to the situation of Roma, Sinti, Travellers and Gypsy communities. ${ }^{140}$ What has been pushed forward in terms of their right to land is the right for nomadic and semi-nomadic communities to have access to halting sites, and, under the European Court of Human Rights jurisprudence, a right to respect for their home. ${ }^{141}$

Other institutions of the Council of Europe have also adopted resolutions and recommendations concerning nomadic indigenous communities in Europe. ${ }^{142}$ In its Recommendation 1203 (1993) on Gypsies in Europe, the Parliamentary Assembly stated: "the provisions of any additional protocol or convention relating

136 ILO Recommendation 104, supra n. 65 at para. 35.

137 Jowitt, Dictionary of English Law, 1st edn (London: Sweet and Maxwell, 1959) at 279.

138 For an overview on the situations of the Travellers, see Keane, 'International Law and the Ethnicity of Irish Travellers', (2005) 11 Washington and Lee Race and Ethnic Ancestry Law Journal 43.

139 As regards Roma/Gypsy communities it is estimated that 20 to 40 percent of the Roma population in Europe retain a nomadic or semi-nomadic lifestyle, see Liegeois and Gheorghe, supra n. 16.

140 For an overview of the situation of the Roma, see Pogany, Accomodating an Emergent National Identity: The Roma of Central and Eastern Europe', (1999) 6 International Journal on Minority and Group Rights 149.

141 See Gilbert, 'Still No Place to Go: Nomadic Peoples' Territorial Rights in Europe', (2004/2005) 4 European Yearbook on Minority Issues 141.

142 See Council of Europe Parliamentary Assembly Recommendation 563 (1969) on the Situation of Gypsies and Other Travellers in Europe, 30 September 1969; Council of Europe Committee of Ministers Resolution (75) 13 on the Social Situation of Nomads in Europe, 22 May 1975; Council of Europe Committee of Ministers Recommendation No. R (83) 1 on Stateless Nomads and Nomads of Undetermined Nationality, 22 February 1983; and Standing Conference of Local and Regional Authorities of Europe Resolution 125 (1981) on the Role and Responsibility of Local and Regional Authorities in Regard to the Cultural and Social Problems of Populations of Nomadic Origin, 29 October 1981. 
to minorities should apply to non-territorial minorities. ${ }^{143}$ In 1998 , the European Commission against Racism and Intolerance adopted a General Policy Recommendation on 'Combating racism and intolerance against Roma/Gypsies' and recommended states 'ensure that the questions relating to "travelling" within a country, in particular regulations concerning residence and town planning, are solved in a way which does not hinder the way of life of the persons concerned. ${ }^{144}$

The Committee on the Elimination of Racial Discrimination has also addressed the situation of Roma communities in its General Recommendation 27. The Committee has recommended that states take measures for offering Roma nomadic groups or Travellers camping places for their caravans, with all necessary facilities. ${ }^{145}$ The Committee also highlighted that states should develop and implement 'policies to avoid segregation of Roma communities in housing', and that states should 'act against discriminatory practices by local authorities and private owners with regard to taking up residences and access housing, to act against local measures denying residence, and refrain from placing Roma in camps outside populated areas that are isolated and without access to health care and other facilities. ${ }^{146}$ The Committee, in its 2003 Concluding Observations to the United Kingdom, pointed out that the discrimination faced by Roma/Gypsies/Travellers was notably reflected in 'poor housing conditions' and the 'lack of available camping sites, ${ }^{147}$ Earlier, in its 1996 Concluding Observations to the United Kingdom, the Committee noted:

Special concern is also expressed for the Irish Traveller community, whose situation affects their right to public health care and social services under article 5(e). It is noted that the policy of designating land for the use of Travellers has contributed to their lower standard of living and has curtailed their freedom of movement by limiting the places which they might inhabit. ${ }^{148}$

Other agencies have also outlined an obligation for states to provide halting sites for nomadic groups. For example, the ILO Office was asked by the Swiss

143 Council of Europe Parliamentary Assembly Recommendation 1203 (1993) on Gypsies in Europe, 2 February 1993.

144 Council of Europe European Commission Against Racism and Intolerance General Policy Recommendation No. 3: Combating Racism and Intolerance Against Roma/Gypsies, 6 March 1998, CRI (98) 29 rev.

145 CERD, General Recomendation XXVII on Discrimination against Roma, 16 August 2000, HRI/GEN/1/Rev.7 at 224; 8 IHRR 310 (2001) at para. 32.

146 Ibid. at para. 31.

147 Concluding Observations of the Committee on the Elimination of Racial Discrimination: United Kingdom of Great Britain and Northern Ireland, 10 December 2003, CERD/C/63/CO/ 11 at para. 22.

148 Concluding Observations of the Committee on the Elimination of Racial Discrimination: United Kingdom of Great Britain and Northern Ireland, 18 March 1996, CERD/C/304/Add.9 at para. 15 . 
government whether in the case of travellers, ILO Convention No. 169 put states under an 'obligation to place at their disposal land for transit purposes or certain sites traditionally used as temporary stopping places. ${ }^{149}$ The ILO Office pointed out that such an obligation would flow from Article 14, but highlighted that:

While the principle of the obligation is clearly established - namely to safeguard the rights of the peoples concerned to use lands not exclusively occupied by them for their traditional activities, with special attention to the situation of nomadic peoples - the modalities of implementation are left up to each Member, subject to compliance with the procedural obligations under the Convention, in particular consultation of the peoples involved. ${ }^{150}$

The Office concluded that in any case 'leeway in terms of implementation does not, however, release a Member party to the Convention from its obligation under Article 14. ${ }^{151}$

Similarly, the OSCE High Commissioner on National Minorities has also focused on the situation of Roma/Gypsies in Europe. The High Commissioner's report of 2000 on the situation of Roma and Sinti in the OSCE stated:

It must be emphasised that whether an individual is nomadic, seminomadic or sedentary should, like other aspects of his or her ethnic identity, be solely a matter of personal choice. The policies of some OSCE participating States have at times breached this principle, either by making a determination of a group's fundamental lifestyle that is inconsistent with its members' choices or by making it virtually impossible for individuals to pursue the lifestyle that expresses their group identity. ${ }^{152}$

The report recommended that for those Roma who 'maintained a nomadic or semi-nomadic lifestyle the availability of legal and suitable parking sites was a paramount need and precondition to the maintenance of their group identity. ${ }^{153}$

Clearly in Europe there is a body of law emerging which recognises a right to encampment for nomadic communities. Even though this has been a European development, it could have significant impact in other regions of the world, as nomadic peoples' right to land would be based on the notion of a right to preserve their own way of life, including a right to halting facilities. 


\section{Conclusion}

As stated at the outset of this article, since the dawn of mankind there have been pressures on the nomadic lifestyle. However, it seems that we have reached a point where nomadic peoples are on the verge of extinction as a result of increasing restrictions on their right to use their traditional itinerant territories. Nomadic peoples are directly affected by economic globalisation as more and more pressure is put on their territories as a result of mining and extraction of natural and mineral resources. Even though nomadic peoples remain at the margin of global capitalist development, they are directly affected by the interests from states and multinational corporations in the natural wealth that can be found in their lands. As this article has pointed out, generally the legal answer to such threats remains extremely underdeveloped as nomadism is not addressed under international law. However, this article has also highlighted that we are witnessing a gradual, albeit slow, development towards a right for nomadic peoples to use their lands and territories in a nomadic way. The establishment of such a legal framework guaranteeing a right for nomadic peoples to perpetuate their nomadic lifestyle is a crucial step to ensuring that nomadic peoples can remain nomads. This article has explored the legal approach towards nomadism. A crucial development under international human rights law is the recognition that nomadic peoples' identity is linked to traditions of mobility. Certainly the most valuable contribution of the human rights discourse is the recognition of the right for nomadic peoples to exercise their own traditional customary systems of land tenure and usage. This article has highlighted the extent to which, under the banner of indigenous peoples' rights, human rights law is promoting the right for nomadic peoples to have their traditional systems of laws recognised by states. This has to be seen as the best path for nomadic peoples' future, as it marks a recognition that they do have the right to be different and that such a right entails their right to maintain their own perspective on the interaction between a people and a territory. After centuries of rejection of such rights under international law, the recent developments that have taken place under human rights law offer great promise. It is also worth highlighting that the recognition of nomadic peoples' right to exercise their own traditions would make the whole human rights system more universal by affirming that all cultures are equal and should be treated equally. By recognising the traditions of nomadic peoples, human rights law reflects the idea that different cultural legal systems could co-exist in the same territory and that there should not be any antagonism between such culturally diverse approaches to land usage.

One of the crucial aspects of this culturally sound approach resides in the fact that human rights law does not assume that cultures are frozen in time, but can evolve and change over time. This means that a human rights-based approach does not assume that nomadic peoples should exercise their rights the way they once did, but takes into consideration that their traditions could change over 
time. The critical message that the human rights approach conveys is that nomadic peoples may choose to develop their nomadic lifestyle if they so wish. This is a welcome advance for an international legal system which for centuries has seen nomadic peoples as 'savages' who should be forced into so-called 'civilization'. These developments within the legal arena also point towards another positive development: with collaboration between different disciplines, it is no longer possible for lawyers and judges to ignore historical, anthropological and social factors when addressing the rights of nomadic peoples. Recent developments clearly indicate that such collaboration is effectively working as regional courts such as the IACtHR, or national courts such as the Supreme Court of Canada, have received evidence based on a multidisciplinary approach. This has to be seen as a positive step in the development of human rights law as the traditional water-tight approach between disciplines was altering the universal and indivisible advancement of human rights.

This point about universalism is central to the situation of nomadic societies. It could seem paradoxical to address the rights of nomadic peoples as a universal phenomenon, as nomadic societies are culturally tremendously diverse and certainly do not represent a homogenised picture. However, despite such diversity nomadic peoples share the same concerns when it comes to their right to use their traditional territories in a nomadic way. In this sense it seems that a global approach would be suitable as there is a need for a universal legal framework specific for nomadic peoples' land usage. There is a need for a stronger human rights approach to the rights of nomadic peoples, as international law is still a system based on the superiority of the settled way of life in which nomadism is regarded as something to be eradicated.

As highlighted, the rules governing territorial ownership emerged from a very Western theory that land has to be 'properly' used and occupied to provide title of ownership. Consequently, historically, nomadic communities have not been regarded as sufficiently 'civilised' to possess rights over their territories. The nomadic system of land use was seen as an outdated and non-rational organisation of land utilisation. Yet, overall, when evaluating the current system, it seems clear that nomadic peoples are gaining rights through the human rights discourse, more specifically under the banner of indigenous peoples' rights. However, this article has highlighted the limitations of this approach and explored the development of a 'nomadic lex specialis'. It is submitted that we are witnessing the development of such a specific body of international law, a 'nomadic lex specialis' that provides nomadic peoples with specific entitlements necessary to the survival of their lifestyle. The current approach seems to be more developed under indigenous peoples' rights, but, as was highlighted, not all nomadic or semi-nomadic communities would qualify as 'indigenous'. There are some limitations for using a channel such as the current system of protection for indigenous peoples as it remains underdeveloped and would not always address nomadic peoples' specific lifestyles. Nomadic peoples have been the 
victims of international law and accordingly there is a need to recognise their specific claims. If indigenous peoples are often labelled as a 'super' minority it could be argued that nomadic peoples constitute a 'super indigenous minority'. In most societies, indigenous nomadic peoples face double discrimination as indigenous peoples or minorities and as being nomadic. Despite the gradual, albeit slow, evolution at the international level regarding the territorial entitlements of nomadic peoples, at the national level they are generally still seen as squatters on their own lands. 